\title{
Research on Progress in Combined Remediation Technologies of Heavy Metal Polluted Sediment
}

\author{
Min Zhang, Xiangchun Wang, Long Yang * and Yangyang Chu \\ China Urban Construction Design \& Research Institute Co. Ltd., Beijing 100120, China; \\ zhangmin@cucd.cn (M.Z.); wangxiangchun@cucd.cn (X.W.); chuyangyang@pku.edu.cn (Y.C.) \\ * Correspondence: yanglong@cucd.cn
}

Received: 6 November 2019; Accepted: 10 December 2019; Published: 13 December 2019

\begin{abstract}
Heavy metals contaminated sediment has become a worldwide environmental issue due to its great harm to human and aquatic organisms. Thus, economical, effective, and environmentally-friendly remediation technologies are urgently needed. Among which, combined remediation technologies have attracted widespread attention for their unique advantages. This paper introduces combined remediation technologies based on physical-, chemical-, and bio-remediation of heavy metal polluted sediments. Firstly, the research progress in physical-chemical, bio-chemical, and inter-organismal (including plants, animals, microorganisms) remediation of heavy metal polluted sediments are summarized. Additionally, the paper analyzes the problems of the process of combined remediation of heavy metals in river sediments and outlooks the future development trends of remediation technologies. Overall, this review provides useful technology references for the control and treatment of heavy metal pollution in river sediments.
\end{abstract}

Keywords: sediment; heavy metal pollution; combined remediation technology

\section{Introduction}

Heavy metals entering water bodies will be accumulated in the riverbed surface sediment through adsorption, complexation, precipitation, etc. Therefore, heavy metal concentrations in sediments are far higher than that in the overlying water. What is worse, once the environmental conditions change, accumulated heavy metals can be released from the sediment through desorption, dissolution, oxidation, and reduction, causing secondary pollution to the water body [1]. Continuous accumulation and migration of heavy metals in sediment will not only pose a serious threat to aquatic organisms and irrigation of farmland along rivers, but also endanger human health via drinking water or food chains [2]. Therefore, treatment and control of heavy metal pollution in sediment should be stressed. These following three aspects are the keys of remediation of heavy metal polluted sediment: (1) eliminate or reduce the environmental toxicity of heavy metals in the sediment; (2) transform the polluted sediment into harmless substances; and (3) isolate and remove the polluted sediment from the water body. Moreover, solving these core problems is of great importance to achieve better treatment and control of the polluted sediment and fine purification of river ecology.

At present, the remediation methods of the heavy metal polluted sediment mainly include physical, chemical, and biological methods. Remediation of heavy metals with a single method may lead to problems such as low efficiency and incomplete remediation, especially in the case of combined pollution with multiple heavy metals in sediment. An integral remediation solution combining two or more remediation technologies will have special superiorities over a single method, including high efficiency and low energy consumption. Combined remediation technologies offer a new approach for remediation of the heavy metal polluted sediments in river courses. This paper summarizes the research progress in combined remediation technology of heavy metal pollution in river sediment 
emerging in recent years in the aim of providing references for the development and application of heavy metal polluted sediment remediation.

\section{Combined Remediation Technology}

\subsection{Physical-Chemical Combined Remediation}

\subsubsection{Electrokinetic Combined Remediation}

Electrokinetic remediation (EKR) is a new multi-disciplinary technology which was first proposed by Acar et al. in 1993. At the early stage, EKR was mainly used for dewatering and the compaction of dams and foundations in civil works [3,4]. However, in recent years, EKR has been applied for soil, sediment, and polluted groundwater remediation, for the purpose of separating and extracting heavy metals from these contaminated areas. Compared to other technologies, EKR has the advantages of obvious effect, convenient operation, less use of chemicals, and avoidance of secondary pollution [5]. The principle of EKR is to remove pollutants by means of electromigration or electroosmosis. Under the action of the electric field, heavy metals migrate towards the electrode chambers through electrodialysis and accumulate in the vicinity of the electrodes, thus realizing the separation of heavy metals from the sediment. Finally, the heavy metals are collected by means of the collection system and concentrated for further treatment [6]. In the process of treating heavy metals with EKR, a large number of $\mathrm{H}^{+}$ions generate from the anodic zone and form an acidic zone. In the meantime, a great number of $\mathrm{OH}^{-}$ ions generate from the cathodic zone. Heavy metals migrate from the anodic zone to the cathodic zone rapidly under the action of the electric field, making them deposit easily on the cathodic zone. Such conditions will influence the removal efficiency of the heavy metals. Luckily, the introduction of chemical enhancers can improve this phenomenon as well as enhance the removal efficiency of heavy metals in sediment. Xie et al. [7] researched the effect of cathodic $\mathrm{pH}$ on the remediation efficiency of heavy metal polluted sediment by acidized-EKR combined remediation technology. In their experiment, acidic cathode cleaning solution was applied to make the pore water in the sediment weak acidic and neutralize $\mathrm{OH}^{-}$ions generated by the cathodes in the electrolytic cell. As a result, the alkalization of the sediment was reduced while the precipitation of heavy metals was effectively prevented. Finally, the removal efficiency of heavy metals by EKR combined with acidic solution was significantly improved. The experiment showed that the removal efficiency was the highest when the $\mathrm{pH}$ value of cathode cleaning solution was 5. Generally, organic acids are used as acid enhancers because most of the complexes generated from them are water-soluble and easy to decompose. On the contrary, inorganic acids are difficult to degrade and may cause secondary pollution. In addition to acidification pretreatment, application of flocculant pretreatment can also significantly enhance the removal effect of heavy metals by EKR. Yang et al. [8] used cationic polyacrylamide as a chemical enhancer to pretreat the polluted sediment in the process of treating cadmium polluted sediment by EKR technology. According to the results, the sediment flocculated after the flocculant pretreatment, resulting in an obvious sediment-water separation. Thus, larger porosity of sediment rendered better channels for ion migration, and the removal efficiency of heavy metals was significantly enhanced. Last but not least, its effect was more obvious than that of the reference experiment with citric acid for acidification pretreatment.

EKR developed rapidly and became more economically feasible in recent years. In addition to the use of chemical enhancers, researchers have also exploited a series of EKR combined methods, including EKR-bioleaching technology, EKR-PRB (permeable reactive barrier) technology, EKR-adsorption technology, and EKR-ion exchange membrane technology (Table 1). The combined application of these technologies can overcome the shortcomings of single remediation technology and significantly improve the effect of EKR on heavy metals, making it a promising remediation technology in the future. 
Table 1. Combined electrokinetic remediation (EKR) technologies.

\begin{tabular}{|c|c|c|}
\hline Combined Remediation Technology & Principle & References \\
\hline EKR-acidification & $\begin{array}{l}\text { The acidic cleaning solution neutralizes the } \mathrm{OH}^{-} \\
\text {produced by the cathode in the electrolytic cell, } \\
\text { eliminates the sediment alkalinization } \\
\text { phenomenon as well as prevents the precipitation } \\
\text { of heavy metals, and finally improves the } \\
\text { removal efficiency of heavy metals. }\end{array}$ & {$[7,9,10]$} \\
\hline EKR-flocculant & $\begin{array}{l}\text { After the flocculant pretreatment, the sediment } \\
\text { undergoes flocculation, resulting in mud-water } \\
\text { separation. The porosity of sediment particles } \\
\text { becomes larger, which provides channels for ion } \\
\text { migration and improves the removal efficiency of } \\
\text { heavy metals. }\end{array}$ & {$[8,11,12]$} \\
\hline EKR-bioleaching & $\begin{array}{l}\text { The microbial activity and acid production } \\
\text { during the biological leaching process transform } \\
\text { the insoluble metal sulfide to soluble metal } \\
\text { sulfate. With the assistance of EKR, the ion } \\
\text { migration speed is accelerated and the removal } \\
\text { efficiency is improved. }\end{array}$ & [13-15] \\
\hline EKR-permeable reactive barrier (PRB) & $\begin{array}{l}\text { This technology combines the advantages of both } \\
\text { EKR and the PRB. Under application of an electric } \\
\text { field, metal ions react with the filling material in } \\
\text { the PRB during the process of migration to the } \\
\text { cathode, which stabilizes the heavy metal ions for } \\
\text { further centralized processing. }\end{array}$ & [16-18] \\
\hline EKR-adsorption & $\begin{array}{l}\text { Under the action of the electric field force, heavy } \\
\text { metal ions migrate to a specific adsorption area, } \\
\text { where in-situ removal of heavy metals is } \\
\text { achieved by being adsorbed by an adsorbent. }\end{array}$ & [19-21] \\
\hline EKR-ion exchange membrane & $\begin{array}{l}\text { Selective semi-permeable membranes are used to } \\
\text { separate the electrodes from the contaminated } \\
\text { soil/sediment, preventing the entry of } \mathrm{OH}^{-} \text {and } \\
\mathrm{H}^{+} \text {, thereby avoiding the alkalization of the } \\
\text { cathode and improving the repair efficiency. }\end{array}$ & [22-24] \\
\hline
\end{tabular}

\subsubsection{Combined Remediation by Chemical Leaching}

Leaching is a frequently used technology which shifts heavy metals from the solid phase of the sediment to the liquid phase for the purpose of cleaning the sediment. Multiple chemicals are added to help extract heavy metals in the leaching process. The following leaching processes are commonly used: acid leaching, complexing agent leaching, and surfactant leaching [25-27]. In the acid leaching process, acidic solution is added to reduce the $\mathrm{pH}$ value of the sediment. The increment of $\mathrm{H}^{+}$ions will compete for binding ligands with heavy metal ions so as to increase the bioavailability content. In the complexing agent leaching process, a chelating agent extracts heavy metals from sediment by forming water-soluble chelates, which leach out heavy metals from the sediment. Particularly, chelating agents with strong complexation capability should be added for treatment of the metal ions that bind closely with the sediment via coordination bonds or covalent bonds. In the surfactant leaching process, the surfactant is applied on the surface of the sediment to remove the heavy metals from the sediment though integration with the metals. During the chemical leaching process, it is a key to select a feasible extractant which can be used to extract heavy metals without damaging the structure of the effective components in the sediment. In fact, it is very difficult to find a perfect one, because any improper addition of an extractant may result in secondary pollution. In practice, researchers try remove heavy metals from sediment by a combined remediation using multiple eluents, which can not only reduce the application quantity of eluents and reduce the risk of secondary pollution, but also effectively improve the efficiency of heavy metal removal. Yuan et al. [28] used the mixture of surfactant 
Triton X-100 and chelating agent ethylenediaminetetraacetic acid (EDTA) to remove heavy metals from sediment. The results showed that the removal rate of $\mathrm{Zn}$ reached $30.0 \%$ by utilizing the mixed solution, which increased $2 \%-5 \%$ compared with cases only using EDTA. Shang [29] chose chelating agent ethylenediamine $\mathrm{N}, \mathrm{N}^{\prime}$-disuccinic acid (EDDS), surfactant hydroxypropyl- $\beta$-cyclodextrin (HPCD), strong oxidizer sodium persulfate $\left(\mathrm{Na}_{2} \mathrm{~S}_{2} \mathrm{O}_{8}\right)$, and Fenton reagent as eluents to repair polluted sediment from the Shenzhen River. These eluents were used individually or in a combined way in order to test the difference of removal efficiency. The results showed that the application of Fenton reagent and sodium persulfate combined eluents $\left(\mathrm{Na}_{2} \mathrm{~S}_{2} \mathrm{O}_{8} / \mathrm{Fe}^{2+}\right)$ could achieve effective removal of heavy metals $\mathrm{Cu}, \mathrm{Cd}, \mathrm{Ni}, \mathrm{Pb}$, and $\mathrm{Zn}$ in the sediment at the same time, and the efficiency was much higher than a single reagent.

The combination of different eluents in the chemical leaching process can improve the remediation efficiency of heavy metal pollution in river sediments, so that it has good development prospects. However, a large quantity of reagents used in the operation process means high cost. What is worse, the medicament that is not fully utilized will cause secondary pollution to the environment. In addition, the removal efficiency of heavy metals is also different under different conditions such as $\mathrm{pH}$, pollutant concentration, eluent formulation ratio, and processing time (Table 2). Therefore, for this remediation technology, it is key to develop and select high-efficiency heavy metal repair eluents and set the most appropriate eluent conditions. The search for chemical eluents with high remediation efficiency, low price, easy degradation, and no secondary pollution poses an important research direction.

Table 2. Effect of leaching conditions on heavy metal removal.

\begin{tabular}{|c|c|c|c|}
\hline Heavy Metal & Condition Variable & Main Results & References \\
\hline $\mathrm{Hg}, \mathrm{Cd}, \mathrm{Cr}, \mathrm{Pb}, \mathrm{Zn}, \mathrm{Ni}$ & Eluent formulation ratio & $\begin{array}{l}\text { When } 2 \% \text { hydrogen peroxide and } 42 \% \text { phosphoric } \\
\text { acid were used to remove heavy metals from the } \\
\text { remaining sludge, the heavy metal removal rates } \\
\text { reached more than } 90 \% \text {. }\end{array}$ & {$[30]$} \\
\hline $\mathrm{Cr}$ & $\begin{array}{l}\text { Eluent concentration, contact } \\
\text { time, liquid/solid ratio, } \mathrm{pH}\end{array}$ & $\begin{array}{l}\text { When the treatment time was } 1 \mathrm{~h} \text {, } \\
\text { the ethylenediaminetetraacetic acid (EDTA) } \\
\text { concentration was } 0.1 \mathrm{~mol} / \mathrm{L} \text {, the soil-liquid mass } \\
\text { ratio was } 1: 10 \text {, and the pH was } 5 \text {, the removal effect } \\
\text { was the best. The removal rate of } \mathrm{Cr} \text { reached as } \\
\text { high as } 22 \% \text { and } \mathrm{Cr}^{6+} \text { was } 98.5 \% \text {. }\end{array}$ & {$[31]$} \\
\hline $\mathrm{Cu}, \mathrm{Zn}, \mathrm{Cr}, \mathrm{Pb}, \mathrm{Ni}, \mathrm{Mn}$ & $\begin{array}{l}\text { Eluent concentration, contact } \\
\text { time, liquid/solid ratio, } \mathrm{pH}\end{array}$ & $\begin{array}{l}\text { Contact time, liquid/solid ratio, and } \mathrm{pH} \text { of washing } \\
\text { agents had notable influence on removal efficiency. } \\
\text { The optimal washing conditions were identified as: } \\
\text { concentration of } 8.0 \mathrm{~g} / \mathrm{L} \text {, contact time of } 24 \mathrm{~h} \text {, } \\
\text { liquid/solid ratio of } 20 / 1 \text {, and original } \mathrm{pH} \text { of } \\
\text { washing agent. }\end{array}$ & [32] \\
\hline $\mathrm{Cu}, \mathrm{Zn}, \mathrm{Pb}, \mathrm{Cd}$ & Liquid/solid ratio, $\mathrm{pH}$ & $\begin{array}{l}\text { When the molar mass ratios of ethylenediamine } \\
N, N^{\prime} \text {-disuccinic acid (EDDS) and ethylenebis } \\
\text { (oxyethylenenitrilo) tetraacetic acid (EGTA) to } \\
\text { heavy metals were } 0.81 \text { and } 3.92 \text {, the pH was } 3.95 \text {, } \\
\text { potential ecological risk index reduction rate can } \\
\text { reach a maximum of } 86.05 \% \text {, and the removal rates } \\
\text { of } \mathrm{Cu}, \mathrm{Zn}, \mathrm{Pb} \text {, and } \mathrm{Cd} \text { were } 72.48 \%, 62.40 \%, 59.25 \% \text {, } \\
\text { and } 87.45 \% \text {, respectively. }\end{array}$ & [33] \\
\hline $\mathrm{Pb}, \mathrm{Cd}$ & $\begin{array}{c}\text { Eluent concentration, contact } \\
\text { time, } \mathrm{pH}\end{array}$ & $\begin{array}{l}\text { With the increase of eluent concentration, } \\
\text { the leaching efficiency of } \mathrm{Pb} \text { and } \mathrm{Cd} \text { generally } \\
\text { showed an upward trend; as the pH of the eluent } \\
\text { increased, the eluent rate generally decreased; as } \\
\text { the eluent time increased, the eluent rate had three } \\
\text { trends: (i) overall increase, (ii) first increase, then } \\
\text { decrease, and (iii) no significant change. }\end{array}$ & [34] \\
\hline
\end{tabular}

\subsubsection{Ultrasonic/Microwave-Chemical Combined Remediation}

Ultrasonic/microwave-chemical remediation technology is a pretreatment of the river sediment utilizing ultrasonic/microwave. The leaching of heavy metals in sediment can be maximized by adjusting the duration of ultrasonic/microwave treatment, and then the leached heavy metals will be further treated with chemical regents. He et al. [35] found that, compared with mechanical 
vibration, ultrasound enhanced the release of $\mathrm{Hg}$ to the water phase in sediments. In the presence of algae, the removal rate of $\mathrm{Hg}^{2+}$ within $15 \mathrm{~min}$ of ultrasound was the same as $60 \mathrm{~min}$ of mechanical vibration. This is because the ultrasonic cavitation destroys the floc structure of the sludge and releases intracellular material from the cell wall, which significantly changes the characteristics of both the dissolved state and particulate matter in the liquid. Therefore, the fixed heavy metals attached to the sludge particles and the floc surface are redissolved, increasing the removal rate of heavy metals. Zhu et al. [36] used composite chemical reagents to remove heavy metals $\mathrm{Cu}, \mathrm{Zn}, \mathrm{Mn}, \mathrm{Cr}$, and $\mathrm{Ni}$ from sediment, meanwhile carrying out the pre-treatment with ultrasonic and microwave, respectively prior to the experiment. Their results showed that the extraction rate of heavy metals in sediment by combined reagents was significantly improved by the ultrasonic and microwave treatment. Moreover, these two physical treatment methods had different optimal treatment time and power, depending on the power density curve. Wu et al. [37] studied the extraction and separation effect of heavy metal ions in sediment under the assistance of ultrasonic wave. In their study, $\mathrm{Cu}-\mathrm{Cr}$ and $\mathrm{Cr}$-Fe sediments were respectively removed by a two-stage method with the assistance of ultrasonic waves. Their results showed that, for the $\mathrm{Cu}-\mathrm{Cr}$ sediment, $96.52 \%$ of $\mathrm{Cu}$ was leached into the solution while $96.64 \%$ of $\mathrm{Cr}$ was retained in the leach residue; for the $\mathrm{Cr}$-Fe sediment, $97.05 \%$ of $\mathrm{Cr}$ was leached into the solution while $98.48 \%$ of Fe was retained in the leach residue. Compared with the acid leach method alone, this combined method had obviously higher extraction rates (extraction rates: $\mathrm{Cu} 97.47 \%$ and $\mathrm{Fe} 1.81 \%$ in the $\mathrm{Cu}-\mathrm{Fe}$ sediment).

The principle of ultrasonic/microwave includes ultrasonic cavitation, mechanical movement, and generation of free radicals. The former two have a strengthening effect on the extraction of heavy metals, while the latter has a significant effect on accelerating the decomposition of refractory organic pollutants. Ultrasound/microwave can also enhance the mass transfer process from solution to adsorbent. Ultrasonic/microwave interacts with the medium during the propagation process, leading to the phase and amplitude change. Therefore, some physical, chemical, and biological properties or states of the medium were changed, resulting in a series of effects including mechanical, thermal, chemical, and biological effects [38]. The main factors influencing the ultrasonic/microwave effect include the ultrasound action time, water content of the sample, and the sound intensity (Table 3). Setting reasonable ultrasonic/microwave processing conditions will significantly improve the repair efficiency.

Table 3. Effects of ultrasound/microwave conditions on heavy metal removal.

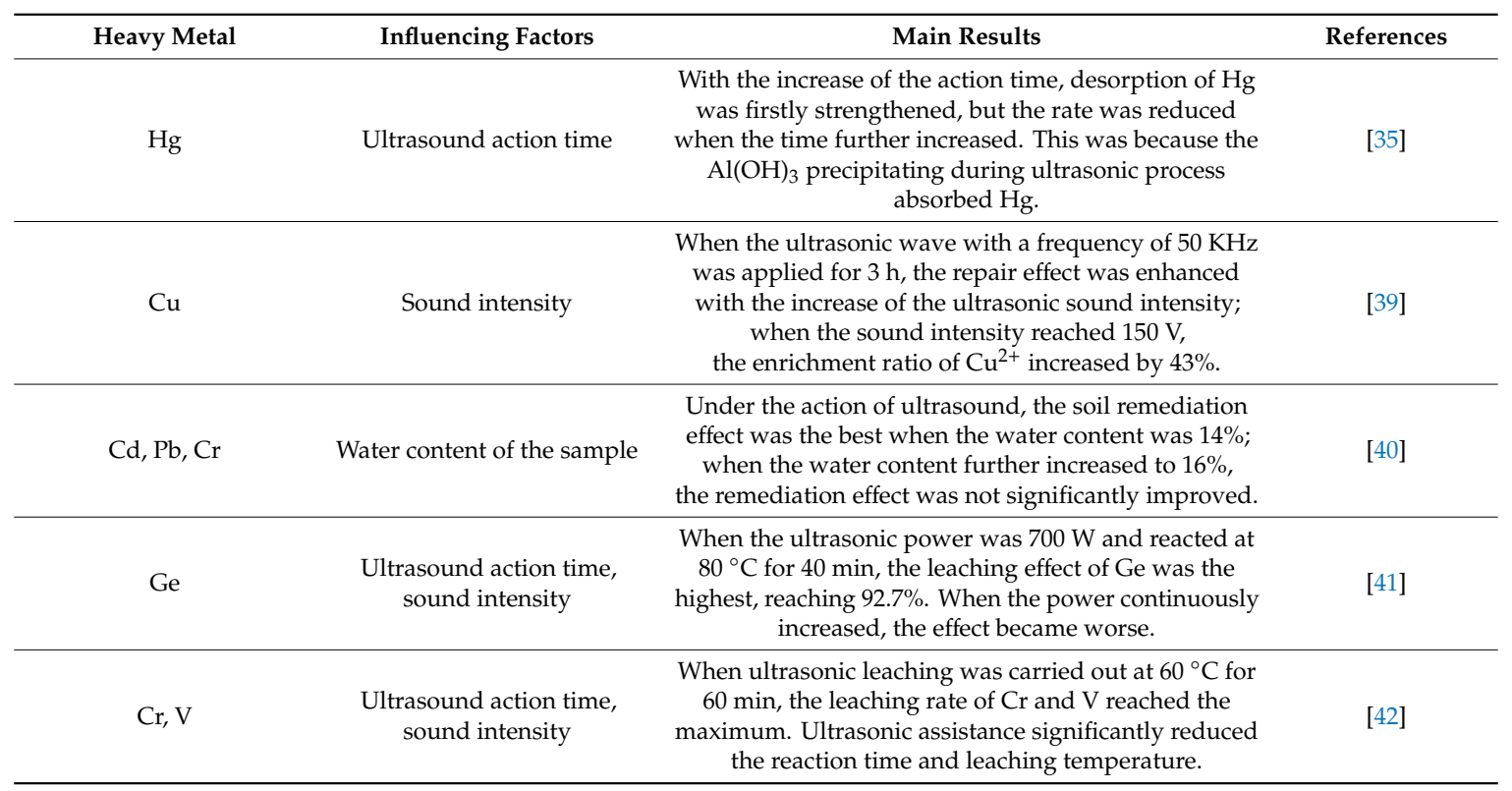


Ultrasonic/microwave-chemical combined remediation improves the extraction efficiency of heavy metals and reduces the use of chemical agents so as to reduce the risk of secondary pollution to the environment. With advantages of high treatment speed, good remediation effect, mild reaction conditions, and the like, it shows a promising application prospect. However, this technology is currently at an initial stage, and further systematization and industrialization is urgently needed. Accordingly, it is necessary to develop efficient and durable reactors and optimize the use of ultrasonic waves under different conditions.

\subsection{Biological-Chemical Combined Remediation}

\subsubsection{Phyto-Stabilizing Agent Combined Remediation}

The phytoremediation mainly uses plants to concentrate and remove heavy metals through phytoabsorption, phytoextraction, phytovolatilization, phytostabilization, and rhizofiltration [43-45]. There are many heavy metal binding sites in plant root cells, which can absorb and enrich heavy metals, and store them in cell walls and vacuoles. Therefore, the toxicity of heavy metals to themselves is reduced. Super-enriched plants are ideal plants for repairing heavy metal pollution. Heavy metals are removed mainly through the extraction of roots, changes of the root environment, assistance of carriers, efficient transfer of root xylem, chemical sedimentation, physical sedimentation, etc. [46]. As early as 1983, American scientists Chaney et al. [47] proposed the idea of removing heavy metals by using plants that can accumulate them. In addition, British scientists Baker et al. [48] stated the practical possibility of removing and recovering heavy metals by hyperaccumulators. Compared with other methods, phytoremediation has the following irreplaceable advantages: lasting effect, low cost, simple post-treatment, good environmental aesthetics, operable heavy metal recovery, less environment disturbance in the treatment process, and generally no secondary pollution [49]. For remediation of heavy metals with plants, it is a key to find out tolerant hyperaccumulators. However, hyperaccumulators usually grow slowly, have lower biomass relatively, and are selective for heavy metals, making them not suitable for treatment of combined pollution with multiple heavy metals. The above shortcoming limits the application of phytoremediation [50]. To improve the removal efficiency of heavy metals in the process of phytoremediation, researchers used the phytochemical method combining chemical remediation by adding chemical modifiers in the process of plant growth.

The chemical stabilizing agent can change the physical and chemical properties of heavy metals in sediment, then change the existing forms of heavy metals in the sediment through adsorption or coprecipitation. Through this process, the available content of heavy metals is reduced and the mobility of heavy metals in the sediment is inhibited for the purpose of remediating heavy metal pollutions in sediment. Based on the existing research, organic acids and minerals have high stabilizing efficiency for heavy metals in sediment [51,52]. At present, hydroxyapatite (HAP), one of the most commonly used chemical stabilizing agents, can directly inhibit the mobility of heavy metals by virtue of its own absorbability. The cations in its structure can exchange with other ions to reduce the activity and availability of heavy metal ions [53]. In addition, hydroxyl groups in HAP can increase the $\mathrm{pH}$ of sediment environment as well as enhance the activity of enzymes. Consequently, the removal of heavy metals by plants was improved [54]. Targeting the severe heavy metal polluted sediments in a river in Zibo, Huang [55] analyzed the removal efficiency of heavy metal polluted sediment using HAP combined with four plant species (i.e., Water mint, Cattails, Maidenhair and Iris). The results showed that the addition of appropriate amounts of HAP could obviously improve the effect of phytoremediation of heavy metal polluted sediments. However, excessive stabilizing agent may reduce the effect of phytoremediation. It is worth noting that this non-permanent measure just changed the existing form of heavy metals in the sediment, heavy metals remain in the sediment, and the stabilized heavy metals may be reactivated with the passage of time, thus having potential risks of secondary pollution. 


\subsubsection{Phyto-Activator Combined Remediation}

Addition of chemical activators can effectively promote the phytoabsorption and phytoextraction of heavy metals by plants. With the reaction of chemical activators, more heavy metals desorb from the surface of sediment particles and transform into more soluble states, increasing the available content of heavy metals in the sediment. As a result, these activators significantly improve the efficiency of phytoremediation of heavy metal pollution. The common types of activators include low-molecular-weight organic acids, chelating agents, and surfactants. The principles of their activation and extraction for heavy metals are basically the same as those of acid leaching, complexing agent leaching, and surfactant leaching in chemical leaching technology. Therefore, there is still a risk of secondary pollution caused by improper control over the addition of chemicals. EDTA is a widely used chelating agent that can chelate with a variety of heavy metals. Due to its poor biodegradability, it is possible to cause environmental risks when applied in the sediment [56]. In addition, previous researches have shown that the capability of the surfactant to activate heavy metals is much higher than that of phytoextraction. Nevertheless, application of surfactants in the process of phytoremediation of heavy metals will inevitably cause secondary pollution while enhancing the phytoremediation efficiency. Compared with the chelating agents and surfactants, low-molecular-weight organic acids are more widely used in practical processes due to their strong activation capability, obvious heavy metal removal effect, and environmental friendliness. Lin et al. [57] used citric acid, glutamic acid $\mathrm{N}, \mathrm{N}$-diacetic acid (GLDA), iminodisuccinic acid (IDS), and saponin to study the effect of their addition amounts on Mn extraction from Chinese fir. The results showed that the application of activators enhanced the Mn removal efficiency of Chinese fir while promoting its growth. The Mn removal efficiency was the highest when the above four low-molecular-weight organic acids were combined and applied simultaneously. Ma et al. [58] explored the effect of citric acid, oxalic acid, and acetic acid on the remediation of lead pollution by wild amaranth plants through indoor pot experiments. The results showed that appropriate addition of organic acid significantly changed the content of $\mathrm{Pb}$ in wild amaranth plants and enhanced the activity of $\mathrm{Pb}$, thus improving the removal capability of plants. Therefore, the combination of the activation function of low molecular weight organic acids with the extraction characteristics of plants has a promising future for the treatment of heavy metal polluted sediments.

\subsection{Combined Inter-Organismal Remediation}

\subsubsection{Phyto-Microorganism Combined Remediation}

Microbial remediation refers to the technology of adding microbial or biological growth promoters to polluted sediment for removing toxic metal pollution or recovering economically valuable metals [59]. There are many related researches about the remediation of organic pollutants by microbes in the early stage, but researches and applications focusing on the remediation of heavy metals are relatively less. In recent years, with deepening research on the effect of microbes in the plant rhizosphere, microbial remediation also has attracted more attention. Although microbes cannot directly degrade heavy metals in the sediment, their metabolism production, including organic acids, surfactants, siderophores, chelating agents as well as their redox actions, can activate or fix heavy metals and improve the remediation efficiency of plants against heavy metal pollution. In the process of plant-microbe joint repair, the action mechanism of microorganisms is mainly reflected in two aspects. On the one hand, microorganisms can regulate the absorption and accumulation of heavy metals by plants by changing the form of heavy metals and expanding the extension range of plant roots in order to promote the extraction of heavy metals by plants and enhance the removal of heavy metals in the sediment. On the other hand, the compartmentalization of heavy metals in microbial cells, chelation, and fixation of metabolites can reduce the ability of heavy metals to migrate, thereby enhancing the plant's ability to retain heavy metals. At the same time, the growth of plant roots secrete protein, sugar, and other organic matter that can be used as nutrient and energy sources of microorganisms, greatly improving the 
bioavailability and activity of microorganisms. Reciprocity and mutual benefit form a symbiotic body, which strengthens their respective roles in the heavy metal contaminated sediment repair process and improves the removal efficiency of heavy metals in sediment. Li et al. [60] conducted pot experiments by maize-ryegrass intercropping with arbuscular mycorrhizae (AM) fungi inoculated to study the effect of phyto-AM fungi on the remediation of river sediment. The results showed that the absorption rate of $\mathrm{Cd}$ by plants significantly increased with the aid of AM fungi, which effectively promoted the activation of the ryegrass for $\mathrm{Cd}$ element. Wu et al. [61] used alfalfa and indigenous microorganisms for remediation of the heavy metal polluted river sediment. The results showed that the heavy metals in the sediment were effectively removed; $\mathrm{Zn}, \mathrm{Ni}, \mathrm{Cr}, \mathrm{Cu}$, and $\mathrm{Pb}$ were accumulated in the root of alfalfa, and Mn was accumulated in the leaves. During the remediation process, root microorganisms also played a repairing and reinforcing effect role. All of these conditions improved the remediation efficiency of heavy metals in the sediment.

The phyto-microorganism combined remediation method is a comparatively ideal remediation method for having certain ecological and economic benefits including low cost and no secondary pollution. However, microorganisms are easy to mutate under the influence of the environment. At the same time, hyperaccumulators have selective adsorption of heavy metals, which are relatively simple in diversity and limited in cumulative capacity. Therefore, potential research directions should seek to improve the efficiency of microbial remediation, adjust the corresponding environmental factors based on the needs of microorganisms as well as seek for or cultivate hyperaccumulators that absorb a variety of heavy metals.

\subsubsection{Phyto-Animal Combined Remediation}

Animal remediation mainly employs a series of life activities such as swallowing, peristalsis, and excretion of benthos such as earthworms, frogs, and shellfishes to promote the remediation process, thus realizing the remediation of the heavy metal polluted sediment by animals. When plants and animals are combined for remediation of the heavy metal polluted sediment, animal activities can form a large number of crisscrossed pore canals in the sediment, increase the porosity of the sediment and gravel layer, and improve the transport rate of water and oxygen in the sediment, thus promoting the growth of plants and root microorganisms [62]. On one hand, animals' secretions can increase the content of available nutrients in sediment, optimizing the living environment of plants so as to promote the growth of plants. On the other hand, a large number of microorganisms in the secretions are also conducive to the remediation process. In addition, the life activities of animals will also affect the $\mathrm{pH}$ value of the sediment environment, causing changes in the occurrence forms of heavy metals in the sediment. As a result, the enrichment of heavy metals by plants was promoted with the assistance of animals. Bai [63] proposed the Eisenia foetida-Chlorophytum combined remediation technology for treatment of heavy metals in the excess sludge based on abundant experiments. The experiments showed that earthworms could change the physical and chemical properties of sludge, promote the growth of Chlorophytum, and enhance the capability of Chlorophytum to absorb heavy metals in sludge. To the sludge with different concentrations of $\mathrm{Cu}, \mathrm{Zn}$, and $\mathrm{Pb}$, the maximum accumulation amount of these three heavy metals in Chlorophytum were up to 8.03, 3.47, and $4.81 \mathrm{mg} / \mathrm{plant}$.

Phyto-animal combined remediation has outstanding advantages including obvious effect, environmental friendliness, and low price, leading to its wide use in the actual operation process. Unfortunately, few kinds of animals can be used for the remediation of the heavy metal pollution. Furthermore, most of them have poor adaptability and their growth and reproduction are easily affected by externalities such as temperature, humidity, and $\mathrm{pH}$, which limits the application and development of this remediation technology to a certain extent.

\section{Research Prospects}

Treatment of heavy metals in the sediment by combined remediation technology can effectively improve remediation efficiency, shorten the remediation cycle, and improve the remediation effect. 
In order to better promote the application of combined remediation methods for heavy metal polluted sediments, the research should be further strengthened in the following aspects:

(1) Seek for or make full use of genetic engineering and other new technologies to cultivate hyperaccumulators with large biomass and strong enrichment capacity that can be used for the remediation of various heavy metals; use microbial technology to screen or develop microbial species that are more conducive to the heavy metal removal and explore the environmental applicability of microorganisms for the sake of improving their remediation availability.

(2) Strengthen the research and development of safe and environmentally-friendly chemical reagents, which not only have a high efficiency on heavy metal removal, but also have better biodegradation, and reduce their environmental risks. More attention should be paid to breaking through the existing technical difficulties and realizing the transformation of heavy metals in polluted sediment to stable precipitate or mineralized substances.

(3) Carry out in-depth research on the mechanism of heavy metal removal by different technologies and try more combinations of various remediation technologies. More efforts shall be spared to get a better efficiency of remediation of heavy metal polluted sediment by optimizing the technology system, reducing the cost, shortening remediation cycle, and avoiding secondary pollution arising from the remediation process.

(4) At present, many remediation technologies are still in the laboratory stage and no remediation projects have been carried out on the actual field. In future work, small and pilot tests of various remediation methods should be strengthened in order to speed up the transformation of these technologies from laboratory to actual engineering application.

\section{Conclusions}

This review specially summarizes the latest research advances in combined remediation technologies of heavy metal polluted sediment. On account of the heterogeneous nature and compositional complexity of sediment, one single physical-, chemical- or bio- method usually cannot achieve the ideal removal affect. Consequently, combined remediation technologies achieve extensive attention for maximizing advantages of the single method and enhancing removal efficiency. Based on the characteristics and application of existing joint repair technologies, more attention should be paid to absorbing the advantages of various repair technologies in the future. Last but not least, the integration and practice of repair technologies are encouraged to make new effective technologies with advantages in repair efficiency, economic cost, environmental friendliness, and scope of application.

Author Contributions: M.Z. contributed to the document collation, method summary and overview, and drafted the manuscript; X.W. and L.Y. revised the manuscript; Y.C. was responsible for visualization.

Funding: This research was funded by Science and Technology Plan of Ministry of Housing and Urban-Rural Development of the People's Republic of China, 2019 (2019-K-142).

Conflicts of Interest: The authors declare no conflicts of interest.

\section{References}

1. Pejman, A.; Bidhendi, G.N.; Ardestani, M.; Saeedi, M.; Baghvand, A. A new index for assessing heavy metals contamination in sediments: A case study. Ecol. Indic. 2015, 58, 365-373. [CrossRef]

2. Zhao, X.J.; Gao, B.; Xu, D.Y.; Gao, L.; Yin, S.H. Heavy metal pollution in sediments of the largest reservoir (Three Gorges Reservoir) in China: A review. Environ. Sci. Pollut. R. 2017, 24, 20844-20858. [CrossRef] [PubMed]

3. Acar, Y.B.; Alshawabkeh, A.N. Principles of electrokinetic remediation. Environ. Sci. Technol. 1993, 27, 2638-2647. [CrossRef]

4. Kim, S.O.; Moon, S.H.; Kim, K.W.; Yun, S.T. Pilot scale study on the ex situ electrokinetic removal of heavy metals from municipal wastewater sludges. Water Res. 2002, 36, 4765-4774. [CrossRef]

5. Pazos, M.; Sanromán, M.A.; Cameselle, C. Improvement in electrokinetic remediation of heavy metal spiked kaolin with the polarity exchange technique. Chemosphere 2006, 62, 817-822. [CrossRef] [PubMed] 
6. Sav, H.; Christopher, J. Integrated in situ soil remediation technology: The Lasagna Process. Environ. Sci. Technol. 1995, 29, 2528-2534.

7. Xie, G.L.; Lin, D.N.; Zeng, C.M.; Wang, D.H.; Liao, Z.M. Effect of cathodic pH control on electrokinetic remediation of heavy metal polluted river sediment. J. Agro. Environ. Sci. 2008, 27, 1140-1145.

8. Yang, L.; Zhang, S.; He, P.; An, X.R.; Wu, Y. Study on influencing factors of electrokinetic remediation of cadmium polluted sediment. S. N. Water Transfers Water Sci. Technol. 2018, 16, 102-107, 121.

9. Meng, F.; Xue, H.; Wang, Y.; Zheng, B.; Wang, J. Citric-acid preacidification enhanced electrokinetic remediation for removal of chromium from chromium-residue-contaminated soil. Environ Technol. 2018, 39, 356-362. [CrossRef]

10. Xue, H.; Meng, F.S.; Wang, Y.Y.; Guo, J.H.; Ji, D.L.; Yang, Q. Remediation of chromium residue-contaminated soil by preacidification electrokinetic remediation. Res. Environ. Sci. 2015, 28, 1317-1323.

11. Juan, A.O.; Peng, C.S.; Ahmed, A.S. Simultaneous removal of cadmium from kaolin and catholyte during soil electrokinetic remediation. Desalination 2012, 300, 1-11.

12. Burlakovs, J.; Lacis, S. Removal of heavy metals from contaminated soils by electrokinetic remediation. In Proceedings of the International Scientific Conference, Research for Rural Development, Jelgava, Latvia, 21-23 May 2014.

13. Peng, G.P.; Tian, G.M.; Liu, J.Z.; Bao, Q.B.; Zang, L. Removal of heavy metals from sewage sludge with a combination of bioleaching and electrokinetic remediation technology. Desalination 2011, 271, 100-104. [CrossRef]

14. Selvi, A.; Aruliah, R. A statistical approach of zinc remediation using acidophilic bacterium via an integrated approach of bioleaching enhanced electrokinetic remediation (BEER) technology. Chemosphere 2018, 207, 753-763. [CrossRef] [PubMed]

15. Xu, Y.; Zhang, C.S.; Zhao, M.H.; Rong, H.W.; Zhang, K.F.; Chen, Q.L. Comparison of bioleaching and electrokinetic remediation processes for removal of heavy metals from wastewater treatment sludge. Chemosphere 2016, 168, 1152-1157. [CrossRef] [PubMed]

16. Xue, F.J.; Yan, Y.J.; Xia, M.; Muhammad, F.; Yu, L.; Xu, F.; Shiau, Y.C.; Li, D.W.; Jiao, B.Q. Electro-kinetic remediation of chromium-contaminated soil by a three-dimensional electrode coupled with a permeable reactive barrier. RSC Adv. 2017, 7, 54797-54805. [CrossRef]

17. Guo, K.; Zhang, Y.J.; Sun, X.; Dong, P. Electrokinetic remediation of gold mine tailings polluted with copper. Chem. Ind. Eng. Prog. 2016, 35, 1237-1241.

18. Zhao, S.N.; Fan, L.; Zhou, M.Y.; Zhu, X.F.; Li, X.L. Remediation of Copper Contaminated Kaolin by Electrokinetics Coupled with Permeable Reactive Barrier. Procedia Environ. Sci. 2016, 31, 274-279. [CrossRef]

19. Ma, J.W.; Wang, F.Y.; Huang, Z.H.; Wang, H. Simultaneous removal of 2,4-dichlorophenol and Cd from soils by electrokinetic remediation combined with activated bamboo charcoal. J. Hazard. Mater. 2010, 176, 715-720. [CrossRef]

20. Zhang, Z.; Ren, W.; Zhang, J.; Zhu, F. Electrokinetic remediation of Pb near the e-waste dismantle site with $\mathrm{Fe}\left(\mathrm{NO}_{3}\right)_{3}$ as cathode electrolyte. Environ. Technol. 2019, 4, 1-10. [CrossRef]

21. Shen, Z.M.; Ju, B.X.; Chen, X.J.; Wang, W.H. Relations between sorption behavior and electrokinetic remediation effect in soils contaminated with heavy metals. Aust. J. Soil. Res. 2008, 46, 485-491. [CrossRef]

22. Chen, X.J.; Shen, Z.M.; Lei, Y.M.; Ju, B.X.; Wang, W.H. Enhanced electrokinetic remediation of Cd and Pb spiked soil coupled with cation exchange membrane. Aust. J. Soil. Res. 2006, 44, 523-529. [CrossRef]

23. Rajic, L.M.; Dalmacija, B.D.; Trickovic, J.S.; Dalmacija, M.B.; Krcmar, D.M. Behavior of zinc, nickel, copper and cadmium during the electrokinetic remediation of sediment from the Great Backa Canal (Serbia). J. Environ. Sci. Heal. C. 2010, 45, 1134-1143. [CrossRef] [PubMed]

24. Naidu, R.; Sreedaran, B.R.; Smith, E. Electroremediation of Lead-Contaminated Kaolinite using Cation Selective Membrane and Different Electrolyte Solutions. Water Air Soil Poll. 2013, 224, 1708. [CrossRef]

25. Abrego, J. Removal of heavy metals from sample of residue sludge. Intern. J. Environ. Pollut. 1996, 6, $295-299$.

26. Palma, L.D.; Mecozzi, R. Heavy metals mobilization from harbor sediments using EDTA and citric acid as chelating agents. J. Hazard. Mater. 2007, 147, 768-775. [CrossRef]

27. Singh, A.; Turner, A. Surfactant-induced mobilization of trace metals from estuarine sediment: Implication. Environ. Pollut. 2009, 157, 646-653. [CrossRef]

28. Yuan, S.H.; Wu, X.F.; Wan, J.Z.; Long, H.Y.; Lu, X.H.; Wu, X.H.; Chen, J. Enhanced washing of HCB and Zn from aged sediments by Tx-100 and EDTA mixed solutions. Geoderma 2010, 156, 119-125. [CrossRef] 
29. Shang, D.D. Experimental Study on Treatment of Polluted Sediments from Urban Rivers by Chemical Leaching Method. Master's Thesis, Harbin Institute of Technology, Shenzhen, China, December 2012.

30. Wu, Z.Y.; You, H.J.; Wang, L.Y.; Xie, G.J. The research of reducing heavy metal in the excess activated sludge. Environ. Prot. Petro. Ind. 2002, 25, 43-46.

31. Li, S.Y.; Chen, J.M. Effect of Chemical Leaching Remedying Chromiunm Contaminated Soil in Deserted Chemical Plant Site. Acta Pedol. Sin. 2015, 52, 869-878.

32. Tang, J.; He, J.Q.; Liu, T.T.; Xin, X.D. Removal of heavy metals with sequential sludge washing techniques using saponin: Optimization conditions, kinetics, removal effectiveness, binding intensity, mobility and mechanism. Rsc. Advances. 2017, 7, 33385-33401. [CrossRef]

33. Xun, Z.X.; Wang, S.Z.; Wang, M.X.; Wang, C.C.; Zhu, Y.Y. Remediation of heavy metal contaminated soil by ultrasound-enhanced washing with EDDS and EGTA. J. Environ. Eng. 2018, 12, 1766-1774.

34. Xu, X.X.; Teng, Y.; Yan, Y.; Wang, G.Y.; Zhang, S.R. Washing removal of Pb and Cd from soil using four plant water extracts. J. Agro. Environ. Sci. 2019, 38, 1954-1962.

35. He, Z.Q.; Traina, S.J.; Bigham, J.M.; Weavers, L.K. Sonolytic Desorption of Mercury from Aluminum Oxide. Environ. Sci. Technol. 2005, 39, 1037-1044. [CrossRef] [PubMed]

36. Zhu, Y.; Wang, S.; Yang, Q.Q.; Yang, Y.K.; Li, L. Extraction effect of physically enhanced composite reagents on heavy metals in sludge. C. Water Waste 2018, 34, 82-86.

37. Wu, Y.D.; Zhang, B.; Huang, Z.Y. Ultrasonic-assisted leaching separation of heavy metals from sludge. Environ. Sci. Technol. 2013, 36, 109-113.

38. Wang, J.; Han, J.T.; Zhang, Y. The application of ultrasound technology in chemical production. Contemporary Chem. Ind. 2002, 12, 187-189.

39. Zhen, X.L.; Zhu, K.; Sun, J.F.; Jiang, Y.F.; Nan, Z.R. Study of electrokinetic remediation on copper-contaminated soil enhanced by ultrasonic. J. Safety. Environ. 2010, 10, 57-60.

40. Zhu, G.X.; Guo, Q.J.; Yang, J.X.; Zhang, H.Z.; Wei, R.F.; Wang, C.Y. Marc P. Research on the effect and technique of remediation for multi-metal contaminated tailing soils. Environ Sci. 2013, 34, 3690-3696.

41. Zhang, L.B.; Guo, W.Q.; Peng, J.H.; Li, J.; Lin, G.; Yu, X. Comparison of ultrasonic-assisted and regular leaching of germanium from by-product of zinc metallurgy. Ultrason. Sonochem. 2016, 31, 143-149. [CrossRef]

42. Wen, J.; Jiang, T.; Gao, H.Y.; Liu, Y.J.; Zheng, X.L.; Xue, X.X. Comparison of Ultrasound-Assisted and Regular Leaching of Vanadium and Chromium from Roasted High Chromium Vanadium Slag. JOM 2018, 70, 155-160. [CrossRef]

43. Raskin, I.; Smith, R.D.; Salt, D.E. Phytoremediation of metals: Using plants to remove pollutants from the environment. Curr. Opin. Biotech. 1997, 8, 221-226. [CrossRef]

44. Adriano, D.C.; Wenzel, W.W.; Blum, W.E.H. Role of Phytoremediation in the establishment of a global soil remediation network. In Proceedings of the International Seminar on Use Plants for Environment Remediation, Kosaikaikan, Japan, 18-19 December 1997.

45. Salt, D.E.; Smith, R.D.; Raskin, I. Phytoremediation. Ann. Rev. Plant Biol. 1998, 49, 643-668. [CrossRef] [PubMed]

46. Chaney, R.L.; Angle, J.S.; Mcintosh, M.S.; Reeves, R.D.; Li, Y.M.; Brewer, E.P.; Chen, K.Y.; Roseberg, R.J.; Perner, H.; Synkowski, E.C.; et al. Using hyperaccumulator plants to phytoextract soil Ni and Cd. Z. Naturforsch. C. 2005, 60, 190-198. [PubMed]

47. Chaney, R.L.; Malik, M.; Li, Y.M.; Brown, S.L.; Brewer, E.P.; Angle, J.S. Baker A.J. Phytoremediation of soil metals. Curr. Opin. Biotech. 1997, 8, 279-284. [CrossRef]

48. Baker, A.J.M.; Brooks, P.R.; Pease, A.J. Studies on copper and cobalt tolerance in three closely related taxa within the genusSilene L. (CaryopHyllaceae) from Zaire. Plant. Soil. 1983, 73, 377-385. [CrossRef]

49. Ali, H.; Khan, E.; Sajad, M.A. Phytoremediation of heavy metals-Concepts and applications. Chemosphere 2013, 91, 869-881. [CrossRef]

50. Tandy, S.; Schulin, R.; Nowack, B. Uptake of Metals during Chelant-Assisted Phytoextraction with EDDS Related to the Solubilized Metal Concentration. Environ. Sci. Technol. 2006, 40, 2753-2758. [CrossRef]

51. Qian, G.; Chen, W.; Lim, T.T.; Chui, P. In-situ stabilization of Pb, Zn, Cu, Cd and Ni in the multi-contaminated sediments with ferrihydrite and apatite composite additives. J. Hazard. Mater. 2009, 170, 1093-1100. [CrossRef] 
52. Yannick, M.P.; Hurel, C.; Geret, F.; Roméo, M.; Marmier, N. Comparison of mineral-based amendments for ex-situ stabilization of trace elements (As, Cd, Cu, Mo, Ni, Zn) in Marine dredged sediments: A pilot-scale experiment. J. Hazard. Mater. 2013, 252-253, 213-219.

53. Wu, P.Q. Clay Mineral Materials and Environmental Remediation; Chemical Industry Press: Beijing, China, 2004.

54. Liu, S.Y.; Li, Y.T.; Obadi, M.; Jiang, Y.Y.; Chen, Z.W.; Jiang, S.J.; Xu, B. Effect of steaming and defatting treatments of oats on the processing and eating quality of noodles with a high oat flour content. J. Cereal. Sci. 2019, 89, 102794. [CrossRef]

55. Huang, L.L. Study on the Effects of Humic Acid and Hydroxyapatite on Phytoremediation of Heavy Metal Polluted Sediment. Master's Thesis, Shandong Jianzhu University, Shandong, China, April 2016.

56. Hu, P.J.; Yang, B.F.; Dong, C.X. Assessment of EDTA heap leaching of an agricultural soil highly contaminated with heavy metals. Chemosphere 2014, 117, 532-537. [CrossRef] [PubMed]

57. Lin, X.Y.; Xiong, Y.W.; Peng, W.Y.; Tang, L.C.; Liang, P.; Huang, L.; Zhou, W.; Xu, J.X.; Li, L. Effect of compound activator and its addition on Mn extraction from Chinese Fir. Environ. Sci. Technol. 2018, 41, 53-57.

58. Ma, L.; Qin, Y.L.; Cai, L.Y.; Zhang, A.P.; Chen, H. Remediation of Pb polluted soil with LMWOA-induced wild amaranth. Chin. J. Environ. Eng. 2017, 11,3861-3865.

59. Zhao, K.H. Environmental Microbiology; Huazhong University of Science and Technology Press: Wuhan, China, 2009.

60. Li, Y.N.; Wang, Y.F.; Wang, G.Y.; Ma, X.L. Phyto-AM fungi combined remediation of composite polluted sediments in polluted rivers. J. Taiyuan U. Technol. 2017, 48, 912-918.

61. Wu, Q.; Gao, Y.J.; Li, D.M.; Zhao, C.Y. Study on the remediation capability of alfalfa to heavy metal polluted sediment. J. Anhui Agric. Sci. 2011, 39, 17376-17378.

62. Dai, J.; Becquer, T.; Rouiller, J.H.; Reversat, G.; Reversat, G.; Reversat, F.B.; Nahmani, J.; Lavelle, P. Heavy metal accumulation by two earthworm species and its relationship to total and DTPA-extractable metals in soils. Soil Biol. Biochem. 2004, 36, 91-98. [CrossRef]

63. Bai, X.Y. Earthworm Sctivation of Heavy Metal Pollution in Excess Sludge-Study on Phytoremediation Mechanism of Flower Plants. Ph.D. Thesis, China University of Mining and Technology, Beijing, China, October 2010.

(C) 2019 by the authors. Licensee MDPI, Basel, Switzerland. This article is an open access article distributed under the terms and conditions of the Creative Commons Attribution (CC BY) license (http://creativecommons.org/licenses/by/4.0/). 